\title{
Problem of urban planning for sustainable development
}

\author{
Elena Smirnova ${ }^{1, *}$ and Vladimir Zaikin ${ }^{1}$ \\ ${ }^{1}$ Saint Petersburg State University of Architecture and Civil Engineering, 190005 Vtoraja \\ Krasnoarmejskaja ul. 4, St. Petersburg, Russia
}

\begin{abstract}
The article deals with the problems of transformation of St. Petersburg industrial territories including the impressive number of monuments of industrial architecture. The work objective: to trace the application of various methods of transformation - reconstruction, restoration and new construction - by way of examples of St. Petersburg historic industrial estates. The examples of renovation of London and Liverpool territories similar in the branch principle to St. Petersburg shipbuilding complexes are used for comparison. The authors contemplate possible ways of modern use of industrial zones, which do not destroy the historical and cultural uniqueness of the urban landscapes. As a result, the authors come to the conclusion about the necessity of taking into account the historical and cultural importance of St. Petersburg industrial territories in the early stage of redevelopment.
\end{abstract}

\section{Introduction}

The intensive activities in transformation of the landscapes formed during the industrial era covered the cities of industrially developed countries from the mid last century. Now the importance of measures for refunctionalization of production territories in the city centre increases. These industrial zones, which are taken out of operation, have obvious investment prospects. They are not used for the purpose intended, worsen ecological indexes of adjacent territories, keeping, however, the transport accessibility and possibility of easy integration into the city infrastructure. The researchers consider a wide range of issues - ecological, socialeconomical, technical, city-planning [1-6].

The question arises about methods of transformation and renovation of such places [7]. In regard to the historic industrial territories, there is also the necessity of taking a number of measures preserving the architectural heritage and its cultural identity [8]. Redevelopment of industrial territories as one of the methods of improving the urban environment is widely used in Europe; it is a part of the modern urbanity policy [9]. Great Britain was the first to start this activity. Large-scale works carried out in London, Manchester, Liverpool, Birmingham, and other cities were the first examples of this kind. Projects of complex redevelopment of the industrial part of London (Docklands), Liverpool (Tea Factory), Rotterdam (Kop van Zuid), Kassel (Unterneustadt) were carried out in the similar way. Initially the strategic objective of developing a depressive territory was set,

\footnotetext{
* Corresponding author: esmirnova@yandex.ru
} 
and then a relevant program and transformation projects were developed. The city authorities applied various schemes of financial participation.

The earliest experiment of transformation of industrial territories was held in London during 1980s [10-11]. Large-scale measures of the territory transformation of the port of London included extensive works on demolition of the major part of old structures which were replaced with office buildings, hotels, shopping centres and residential buildings. The renovation included radical transformations, with new construction prevalence, even though some measures were taken to preserve and restore certain warehouses and structures with old Victorian features. London Docklands Development Corporation created in 1980 became the important body in the course of the port transformation; it carried out renovation works with support of the English Heritage Fund [12-13].

The development strategy for the architectural-spatial environment in Liverpool provided for a high degree of preservation of historic industrial territories with extensive restoration and reconstruction of the unique complex of port structures. The transformation program was based on the thorough substantiation prepared by the specialists in preservation of historic and urban memorials [14-15].

France, if only a little later, but on lesser scale, carried out such well-known transformation works as renovation of d'Orsay railway station, la Villette complex, Menier chocolate factory. Berlin, Hamburg and Leipzig — the cities in the Ruhr basin (Germany) - are involved in rehabilitation and transformation of large industrial territories. This process is also relevant to St. Petersburg - one of the leading cultural and industrial centres in Russia.

\subsection{Background}

Saint Petersburg was founded by Tsar Peter the Great in 1703. Between 1713-1728 and 1732-1918, St. Petersburg was the imperial capital of Russia. St. Petersburg was renamed as Petrograd in 1914, as Leningrad in 1924, and in 1991 it returned its initial name, St. Petersburg. It is Russia's second largest city after Moscow with 5 million inhabitants and the fourth most populated federal subject. St. Petersburg is a major European cultural centre, and also an important Russian port on the Baltic Sea. The "Palmyra of the North" and the "Venice of the North" are popular pseudonyms of St. Petersburg found in journalistic essays and works of art of 18-20 centuries. St. Petersburg is often described as the most Western city of Russia, as well as its cultural capital. The Historic Centre of St. Petersburg and Related Groups of Monuments constitute a UNESCO World Heritage Site [16].

Industrial architecture has a special place in the cultural space of St. Petersburg. From the very foundation, its unique image was formed, along with the main centre, by facility buildings and complexes, which surrounded the historic centre by solid redbrick buildings with huge chimneys and water towers. Unlike other European capitals, St. Petersburg was fully touched by urbanistic transformations neither in the prerevolutionary period nor during the Soviet power. The historically developed industrial zone became an intermediate zone between the centre and new socialistic quarters. These "closed" industrial territories occupy an area three times exceeding the historic centre. They are a reserve for taking urban pressure off the historic sections and accelerate forming new spaces and landscapes. All this presupposes elaboration of an urban strategy for refunctionalization of the industrial territories with consideration of architectural-planning particular features of the urban environment. The water orientation of industry is also typical for St. Petersburg that had been built not only as a capital city, but also as a large port. The port and shipbuilding complexes, textile and cotton factories occupy wide territories on the river banks. 
It should be noted that the above example of Liverpool much better fits the objective of preservation of the historical memory and identity of cultural heritage of St. Petersburg (in comparison with Moscow) [17]. However, in regard to industrial territories, application of such methods in a pure form rarely takes place. The examples combining restoration and reconstruction with inclusion of new construction are the most realizable. Similar prospects are also outlined in regard to St. Petersburg industrial territories.

\subsection{Redevelopment policy}

Development of the refunctionalization strategy for all the industrial zone of St. Petersburg is in the early stage. It is included into the issues of St. Petersburg new general layout of 2018. Now the inventory of all industrial territories, specification of their ownership and purpose of use is being carried out. 26 large zones situated near the historic centre are specified among the industrial territories intended for redevelopment (Figure 1).

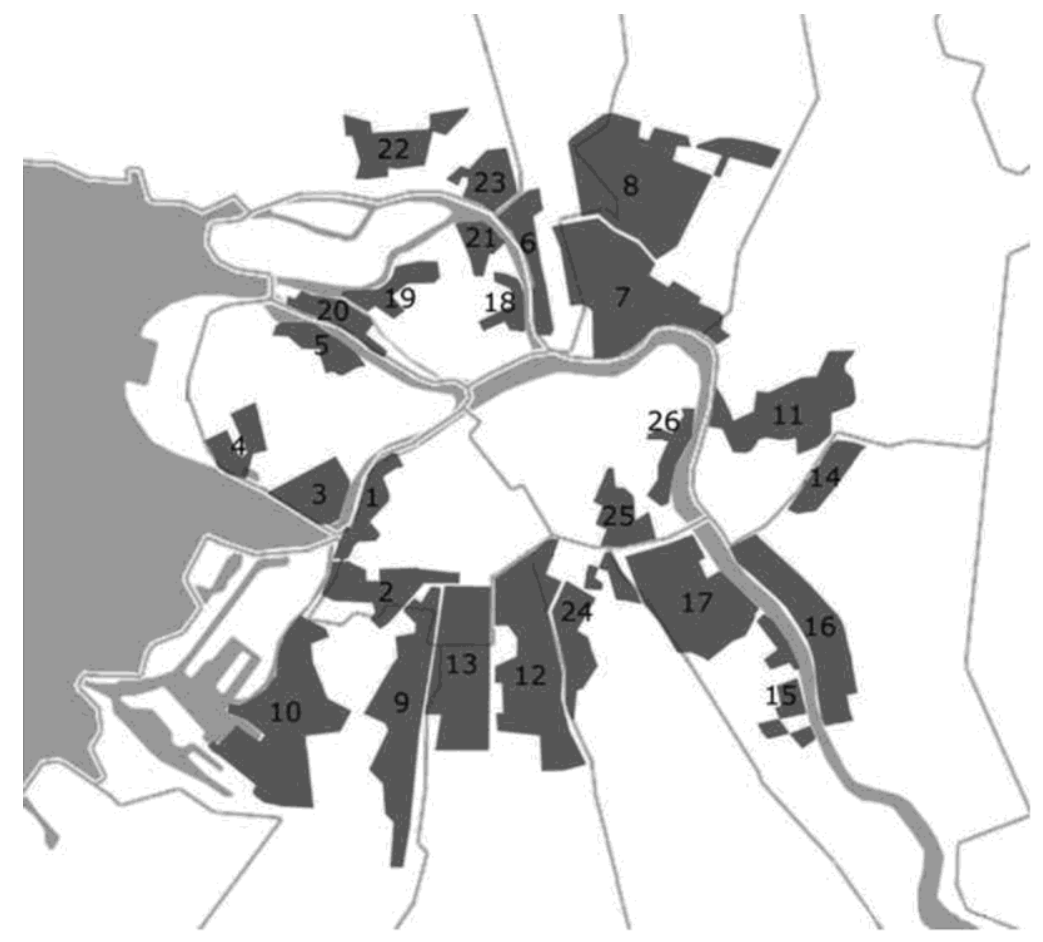

Fig. 1. Location of industrial zones for redevelopment. Diagram (see www.peterland.info).

Distinctive characteristics of St. Petersburg industrial territories, which are subject to cityplanning transformation:

- Location in the historically developed territories - mainly in the city centre, along waterways;

- Area from 50 ha and more;

- Nonconformity to modern city-planning norms (to the General layout and rules for land use and development of St. Petersburg);

- Considerable fullness of industrial zones, lack of any reserve for development;

- Good engineering and transport preparedness of the territory and, at the same time, a high degree of wear of utility networks, lack of any considerable reserve of capacity growth; 
- Considerable part of the enterprises in industrial zones does not carry on intensive production activity any more, essential parts of the territory are used for a purpose other than their intended use;

- High cost of the land.

Many of the complexes contain valuable objects of industrial architecture (buildings, constructions, complexes) included in the Lists of the Objects of Cultural Heritage of Regional (St. Petersburg) or Federal (the Russian Federation) Significance. They are under the state protection according to the law of the Russian Federation; however, they are not the part of the UNESCO World Heritage Site "The Historic Centre of Saint Petersburg and Related Groups of Monuments".

\section{Materials and Methods}

This work introduces the results of the author's observations, research and expert opinions. One of the authors in 1993-2001 took part in the work of the Committee for Protection and Use of Saint Petersburg Monuments on drawing up Lists of the protected industrial facilities, and now he is involved in discussion of "Development of the strategy for industrial zones redevelopment on preparation of proposals for use and Involvement In economic turnover of the industrial territories adjacent to the historic centre of Saint Petersburg".

The review of several historical industrial territories of St. Petersburg contained in the article is intended to show their high architectural advantages, an important city-planning role in water panoramas, close combination with the main centre. The largest complexes, the most significant in historical-cultural relation, having significant city-planning importance and attracting keen interest of citizens and specialists were selected for consideration. These objects differ in the sector profile, composition peculiarities and location in the urban landscape. The safety of the historical-cultural importance and architectural-planning features of the objects are considered to be the priority criterion in making assessment of the results of transformation. This criterion was chosen as the most significant in conditions of orientation of the general city-planning policy to preservation of St. Petersburg identity and increase of its touristic attractiveness.

\section{Results}

\subsection{Admiralty Shipbuilding Plant}

By the scale and potential effect, transformation of this complex can be compared to the famous renovation projects of dockyards In London and Liverpool [18-19]. Refunctionalization of the plant makes it possible to restore the lost fragment of the Neva panorama. The very name of the Admiralty Shipbuilding Plant reminds of the Admiralty the first shipyard in Russia. In early XIX century, the shipbuilding plant was relocated here from the main Admiralty, downstream from the river, farther from the Winter Palace. St. Petersburg architects of the classicism epoch were aware of the importance of construction in the Neva's delta, as a sea gateway into the city. The architectural idea of the New Admiralty (which is its historical name) during the early stage took into consideration its importance for urban environment; it was conceived according to the classical principles of composition. In the shore area, an embankment, quays, iron gates with trellis-works, and bridges were built. Two large stone boathouses and workshops formed the shore landscape completed with the temple "Savior on Waters" - the memorial to Russian seamen perished in the Tsusima battle of the Russo-Japanese War of 1904-1905 (Figure 2). 


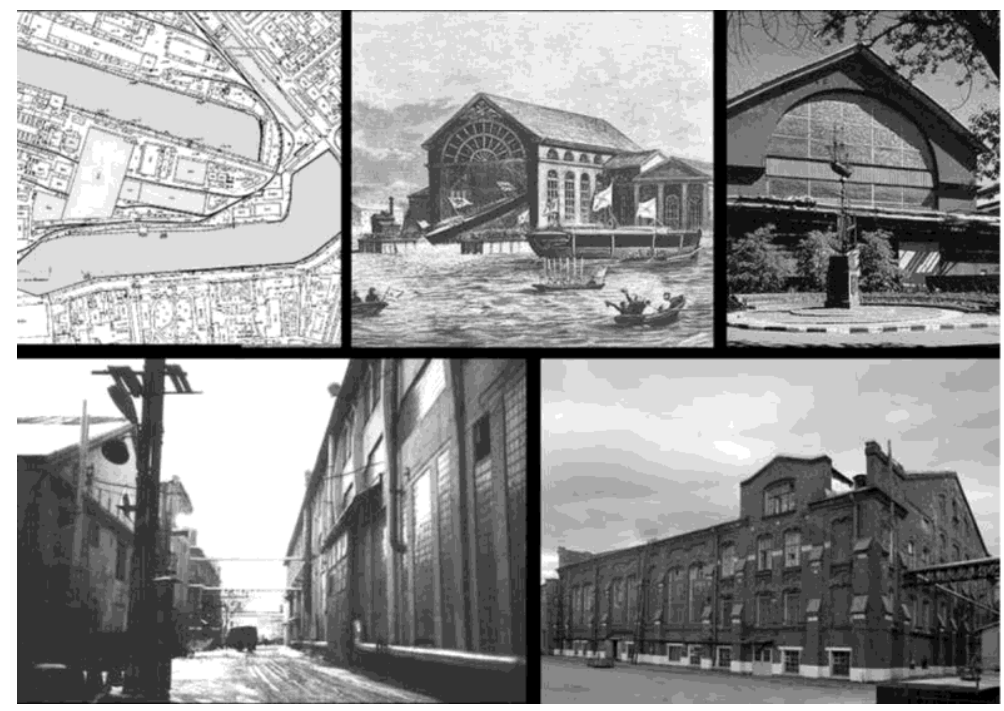

Fig. 2. Admiralty Shipbuilding Plant.

The New Admiralty shares the fate of many plants in St. Petersburg, which are in dire need for renovation. Artificial and natural water bodies and rivers, in combination with unique bridge structures, make it possible to locate various functions on the territory now available for new construction, urgently needed by the city. It is obvious that this territory is highly attractive for the city. The ideas of renovating this area were put forward as early as the beginning of the XX century by an engineer of this plant N.I. Dmitriev, who suggested that the industry should have been relocated away from the city, whereas the buildings should have been transformed into a residential area instead [20]. It got a new impulse in 2012-2013, due to the construction of a new bridge across the Neva River. In addition, it was necessary to exempt the territory from production and to remove shipbuilding out of the city.

In this situation, it was necessary to consider the concentration of industrial architectural monuments in the shore area, their regular positioning and orientation towards the Neva River: restoration of the lost panorama of the shore - reconstruction of the demolished temple, clearing of the stone boathouses from later additions from the shore-side. New construction is only allowed on part of the territory along the bank of the Moika River. Thus, a high degree of the exempted industrial environment needs serious biological treatment.

It was intended that the part of production would remain in its place as before, and the facilities only of the civil surface shipbuilding would be transferred to a new dockyard in Kronstadt. Now the process of refunctionalization of the Admiralty Shipbuilding Plant is delayed due to the cancellation of the decision about bridge construction in the draft of the new general layout of 2018 [21].

\section{2 "Bermuda triangle"}

The other oldest enterprise connected with shipbuilding is situated not far from the Admiralty Plant — the warehouses for ship timber - the "New Holland".

This masterpiece of late classicism has become one of the city's symbols, but, during the soviet times, it was a closed area and it was used as a military warehouse complex. Starting with early 1990 s, failed attempts to regenerate and restore it have been made so as to transform it into a multifunctional cultural and tourism complex. For a long time, this 
triangular island in the centre of St. Petersburg has been a kind of a "Bermuda triangle": owners changed, territories were cleared, when not only insignificant buildings were demolished, but also the so-called "experimental" basin, which is very important as a historical and technical object.

As a result of all the transformations and activities of the new owner, Roman Abramovich, in 2010 the invitation to bid was announced, and LLC "New Holland Development" became a successful bidder. In 2011, a competition for the concept of the future development of the monument was announced, with consideration of the expert opinions (including authors of the article), and citizens' recommendations. In accordance with the winner project, offered by the American architectural bureau WorkAC, the existing buildings will be reconstructed into artistic and commercial structures, and the building of the prison will become a hotel. Mainly, restoration and adaptation of the preserved historic buildings with a minimum of new construction is planned here [22]. In 2014 the architect bureau "WEST-8" from Holland joined the design.

While preparing the project and the concept of the complex adaptation, the new owner proceeded to its real reclamation, being guided by the "starting landscape" technique. Along with the conservation and restoration of the buildings, the works on remediation and gardening of space are being carried out. Green lawns, vegetable gardens, flowerbeds and various temporary pavilions, which are used in a number of different ways - from rest on the lawns to work on the vegetable gardens - are spread out over the free areas. Such an approach makes it possible to attract public interest and improve the ecological situation, which is very topical for the city centre (Figure 3).

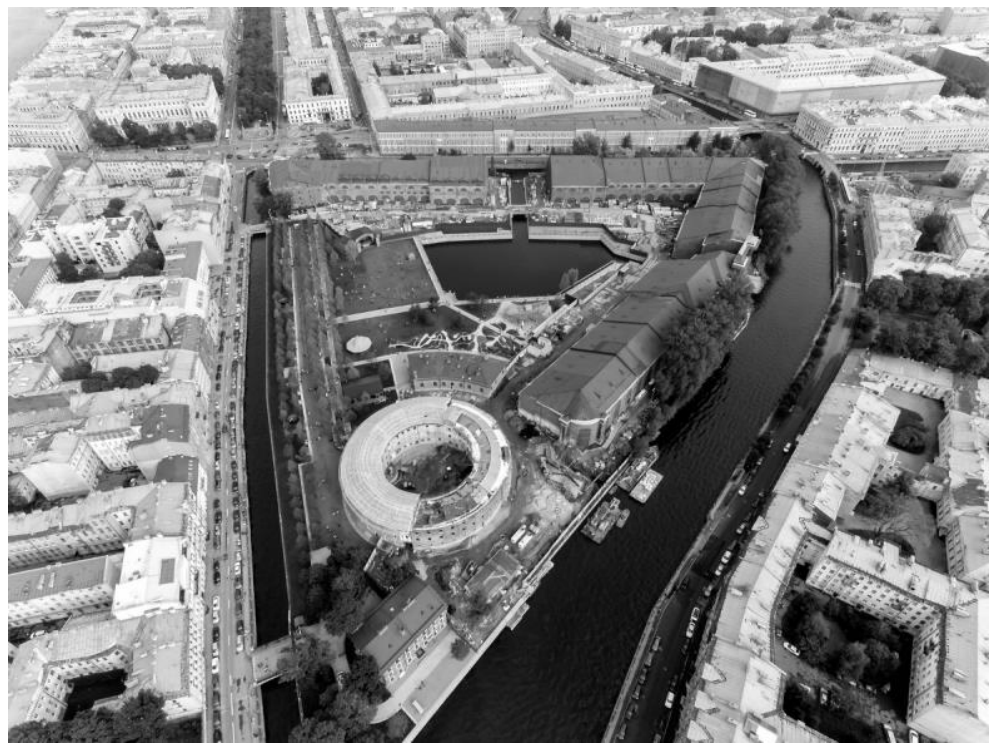

Fig. 3. New Holland. Final Landscape.

\subsection{Nevskaya Paper Mill and Thread Factory of Baron Stieglitz}

Among the oldest factories, this object is one of the most notable in St. Petersburg. The multi-faced composition of the factory complex is spread both along the embankment front and deep into the area away from the shore. In the Neva's perspective, redbrick buildings are combined with arched girders of the Bolsheokhtinsky Bridge and the Smolny Monastery silhouette, which forms a unique and dramatic landscape (Figure 4). 




Fig. 4. The first high-rise factories in the age of industrial revolution (the mid- XIXth century): Albion Mill, Worcester \& Birmingham Canal, England (left) and Nevskaya Paper Mill.

There are tall chimneys towering over long buildings, resembling giant pillars. These chimneys of the factory - the signature elements and urban focus objects - were romantically named "Faith", "Hope" and "Love" (Russian female names Vera, Nadezhda, Lubov). Before 2010, they had been the decoration of the panorama of the Sinop embankment. Despite the status of state-protected objects, the chimneys were torn down.

Banker baron Ludwig von Stieglitz founded the "Nevskaya manufaktura" in 1833. The main multi-level industrial buildings surround the territory of the factory from three sides. The main facade of the latest construction outlooks the Neva River; it belongs to the socalled "Second weaving mill". It was built in 1895, according to the architect L.L. Peterson's project. A picturesque perfection, a rich pattern of the wall abundant with brick decorations, windows varying in size and shape, metal decorations - all this yields rare decorativeness to the building. It prevails in the complex redevelopment and the Neva panorama (Figure 5).

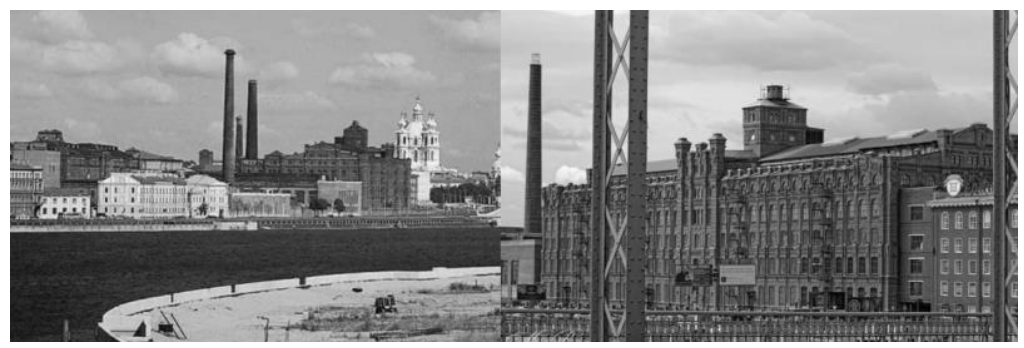

Fig. 5. Panorama of Nevskaya Paper Mill and Second weaving mill building.

Its background is the building of the Thread-Weaving Factory built according to the architect P.S. Kupinskij's project in 1888, with another level built in 1892 by L.L. Peterson. This building also belongs to the late "brick style". Facade decorations are somewhat scarce, which is compensated with large shapes and a picturesque silhouette due to tentshaped towers on either side.

In this complex, the most utilitarian in the architecture and city planning role is the building of the First weaving factory built according to the military engineer L.V. Glamy's project during 1850s. Its side wall overlooks the Neva River and it is perpendicular to other two factories. Undecorated redbrick walls, rectangular windows and simple attic belt - all this makes the architecture of this building similar to multi-level English factories of the era of industrial revolution in mid XIX century. Inside the territory boiler house and a few low industrial buildings covered with huge facade buildings are located. Production is partially relocated away from the territory, with buildings restored and reconstructed (Figure 6). 


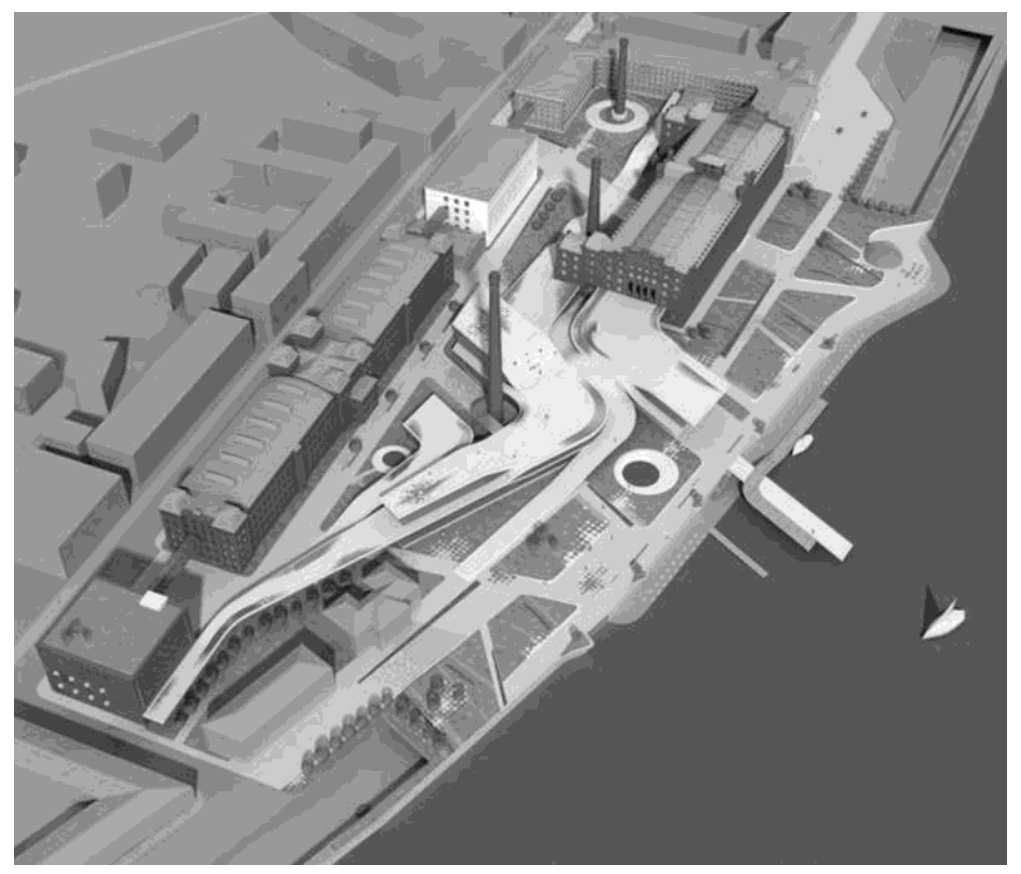

Fig. 6. Nevskaya Paper Mill and Thread Factory renovation project.

The project is mainly financed through mortgage of the land and real estate objects of the industrial complex. The total amount of investment is $\$ 138 \mathrm{mln}$. The main leaseholders of the renovated buildings are state authorities: The Integrated Document Centre, the Road Police, the Federal Registration Service.

An important compositional role of the complex in the panorama of the Neva embankment predetermined the direction of transformation with predominance of restoration of historical buildings, with partial reconstruction, and a minimum of new inclusions of the elements of purely technical character. Successful renovation of this industrial territory (with a large degree of restoration and reconstruction) is probably conditioned by the fact that the implementation of the government-funded project is not connected with the risks of economic character as in case of the private investor.

\section{Discussion}

\subsection{Industrial complexes of Leningrad avant-garde}

\subsection{1 "Krasnoye Znamya"}

The industrial architecture of Leningrad that coincided with the heyday of Russian avantgarde is represented by outstanding memorials, some of which are world-class masterpieces. These include, first of all, the textile clothing factory "Krasnoye Znamya" built in 1926-1930 according to the prominent German architect Erich Mendelssohn's project (Figure 7). 


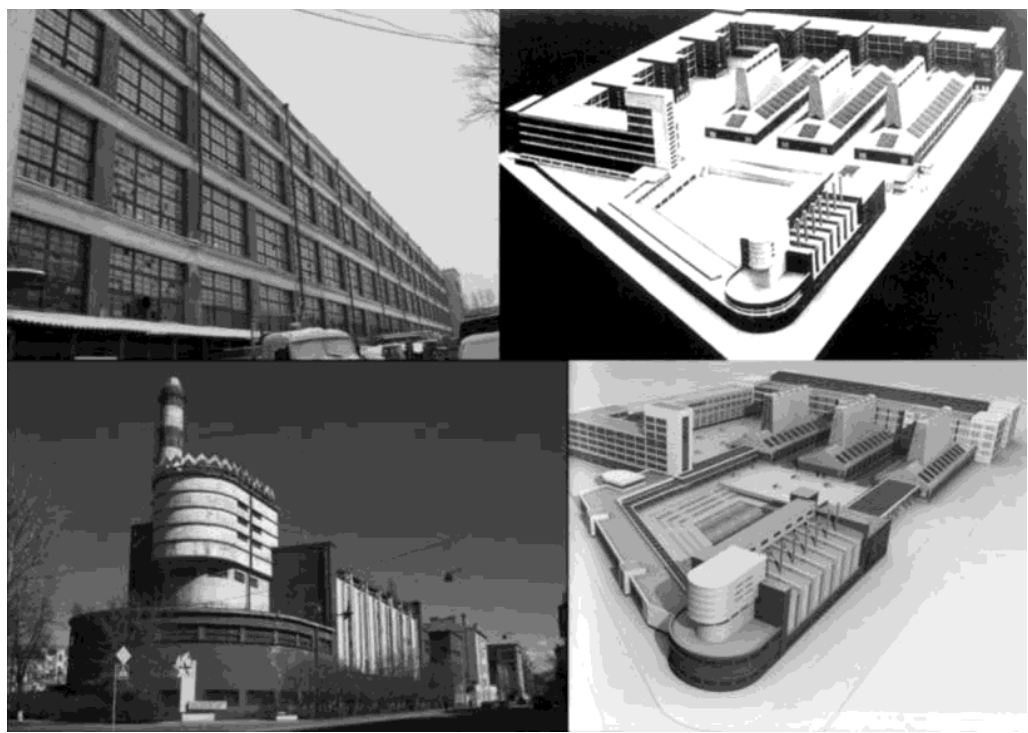

Fig. 7. Factory "Krasnoye Znamya"

The complex includes a four-level textile shop, three workshops and a power distribution station. This audacious work of plastic art located at the corner of the block and prevailing in the ensemble combines the features of expressionism and functionalism, and embodies the credo of the author "function plus dynamics". The building still looks authentic, but it is in a very bad state. Mendelssohn compared the building of the power distribution station to a "ship towing the entire production forward". The image of the building is set with angular volumes containing water-treatment facilities (sediment pools, filters, a pumping room). The upper volume emphasized with girders contains a water tank.

The reconstruction project of the architectural complex "Krasnoye Znamya" was taken over by a St. Petersburg businessman Igor Burdinsky. The investor planned to transform the half-destroyed factory buildings into a modern multi-functional complex. Preliminary assessment states the cost of the project to be $\$ 500 \mathrm{mln}$. Burdinsky made it clear: all the buildings, except the legendary Heating station by Erich Mendelssohn, should be excluded from the "cultural heritage" lists, whereas 1 ha of the land area should be assigned to the residential complex. The German architects of the architectural bureau Kramm \& Strigl suggested that one of the buildings of the factory should be reconstructed as a businesscentre with the area of 25 thousand $\mathrm{m}^{2}$. Besides, the project implied the construction of a hotel for 280 rooms and an exhibition complex with the area of 5-7 thousand $\mathrm{m}^{2}$. The power distribution station by Erich Mendelssohn with the area of 6 thousand $\mathrm{m}^{2}$ was to be reconstructed as a modern art museum. The total area of the new, restored, and reconstructed real estate property was supposed to reach 100 thousand $\mathrm{m}^{2}$. In fact, the historical planning of Mendelssohn would have been lost in case of such a decision.

However, the bodies of protection of St. Petersburg monuments and the experts supported by the public did not allow excluding the buildings from the List of Cultural Heritage Objects, and, therefore, rebuilding the historical complex cardinally. Without relying on receiving the expected economic benefit and financial support of the city authorities in this case, the investor left the territory, having put it out to tender. Now the change of ownership and development of a new concept, primarily fulfilling the conditions of preservation of architectural features of this outstanding avant-garde memorial, are expected. 
According to specialists, transformation of the textile clothing factory "Krasnoye Znamya" territory implies zoning and use of three methods dictated by the existing urban environment. Firstly, the restoration of the power station. The second method is reconstruction of the workshop buildings that have largely lost their historic details. And, in the third zone, new construction is possible that would coincide as much as possible with the initial idea of the great German architect [23].

\subsubsection{Meat-Packing Plant named after S.M. Kirov}

Another masterpiece of soviet avant-garde architecture - the Meat-Packing Plant named after S.M. Kirov — is one of the most significant achievements of Leningrad constructivism. It was awarded a Grand Prix for its engineering and architectural outstanding features on the international exhibition in Paris in 1937 (Figure 8).

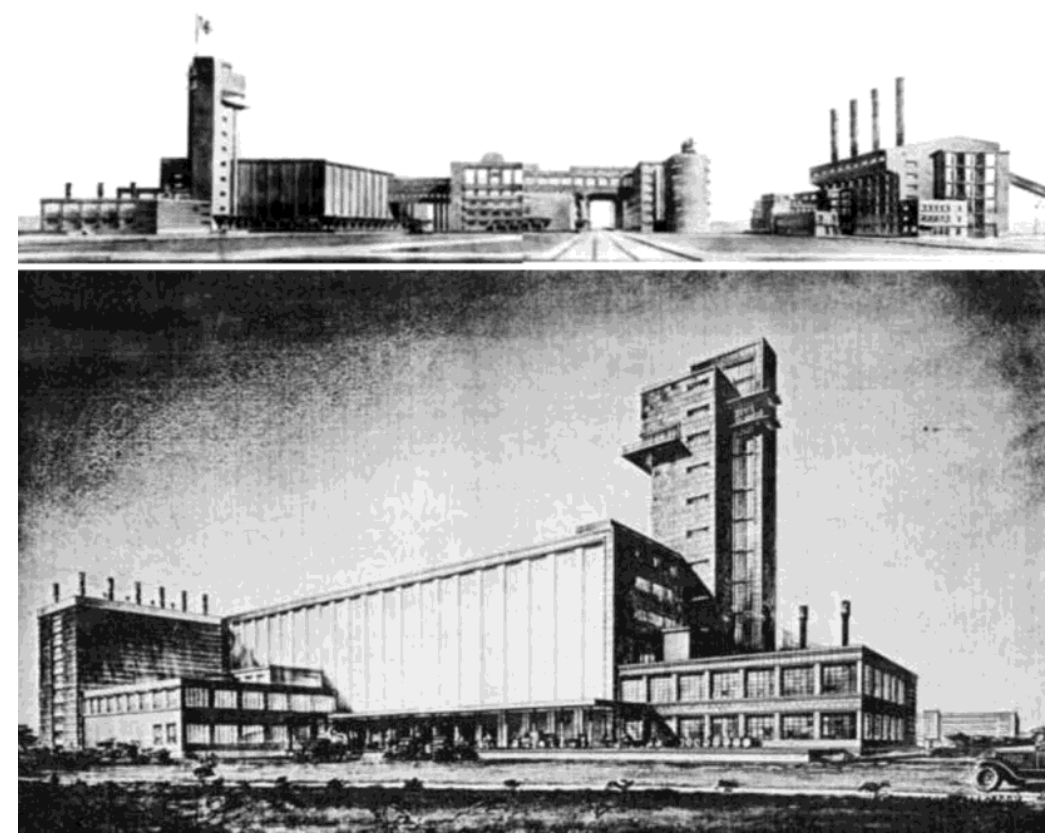

Fig. 8. Meat-Packing Plant named after S. M. Kirov. 1930-1933.

The complex was created in 1931-1933 by a group of engineers and architects under general supervision of one of the leading Leningrad architects N.A. Trotsky. Built on the southern outskirts of the city, the Meat-Packing Plant, with its unforgettable skyline, prevailed over an extensive territory. The sausage-freezing shop forms the foreground, with its 54-meter high water tower.

The ensemble of production buildings is integrated architecturally and technologically into one architectural-spatial composition with a park and a square, dating back to Bauhaus principles. The main office at the entrance the factory territory, as well as the checkpoints and the main gateway are decorated with bronze bull statues on high pedestals made from dark-read polished granite. Auxiliary buildings are on both sides of the main production buildings. This part of the territory, with its utility buildings, which was more than once reconstructed during 1960s and 1980s, can be allocated to new construction.

The group of companies "Samson" controlled by the Industrial Bank of Moscow has developed a project of renovation of this territory involving construction of 1 million $\mathrm{m} 2$ of 
residential property, 600 thousand $\mathrm{m}^{2}$ of commercial real estate and minimum preservation of historic buildings. The concept offered by investors and assuming preponderance of new residential construction over the preservation methods has not received approval of the expert community, according to which methods of restoration and reconstruction of historic buildings and preservation of their prevailing value in the environment shall be of top priority. At the moment, the complex is in disrepair.

\section{Conclusions}

The rich history reflected in the unique city architecture places its restrictions on formation of the urban policy. As many objects are included in the list of the protected ones, the transformation of the central districts of the city becomes a challenging task for prospective investors. The legislation forbids demolishing old buildings completely and starting new construction, and it is too expensive to preserve authenticity of the objects. New owners interested in receiving the maximum profit have no benefits inducing them to preserve monuments, thus all the difficulties concerning legal and infrastructure preparation of the constructible surface fall on investors.

So, now the majority of the measures for transformation of territories in the city take place chaotically. The historical industrial environment of St. Petersburg, which is in many regards similar to European industrial cities, is being renovated and reformed, however, in insufficient rates. The main reason constraining the movement of St. Petersburg redevelopment to the world practice is that the city authorities do not have a complex strategy for industrial territories development. It is in the early stage of development. The part of the transformations of the industrial zone covers only $11 \%$. No more than one third of St. Petersburg industrial zones (about 2 thousand ha) intended for redevelopment can be interesting to the private business.

When working out the complex strategy for St. Petersburg industrial territories redevelopment, it is necessary to analyse the specific industrial territories, which become available, and to identify their historical-cultural constituents and priority of such transformation methods of historical-industrial estates as restoration, reconstruction, recreation, "starting landscape". Elaboration of the approaches to solution of these problems shall also be based on the study of foreign experience. This will make it possible to predict and optimize the process of industrial zones transformation so as to preserve the unique historical environment of St/ Petersburg.

\section{References}

1. J. Alfrey, T. Putnam, The Industrial heritage: Managing resources and uses (Routledge, London, New York, 1992)

2. R. Granger, Proceed. of the Inst. of Civ. Engineers - Urban Design and Planning 163(1), 9-16 (2010)

3. N. Cossons, XVth TICCIH International Congress 2012, The International Conservation for the Industrial Heritage (Chung Yuan Christian University, Chung Li, Taiwan, 2013)

4. V. Nefedov, M. Stiglic, Word Appl. Sci. J. 23(13), 70-73 (2013)

5. J. Skaloš, I. Kašparová, Ecol. Engineering 43, 60-69 (2012)

6. E. Smirnova, Espacios 39(22), 40 (2018)

7. D. Cowan, Proceed. of the Inst. of Civ. Engineers - Civ. Engineering 163(6), 56-63 (2010) 
8. R. Banerjee, P. Srivastava, Land Use Policy 34, 193-203 (2013)

9. D. Latham, Creative re-use of buildings (Donhead Publishing, Shaftesbury, 2000)

10. M. Stratton, Industrial buildings: Conservation and regeneration (E \& FN Spon, London, New York, 2000)

11. D. Pearce, Conservation today: Conservation in Britain since 1975 (Taylor and Francis, Hoboken, 2014)

12. M. Stratton, Water and industrial heritage: the reuse of industrial and port structures in European cities on water (Marsilio Editori, Venice, 1999)

13. G. Marshall, London's industrial heritage (The History Press, Stroud, Gloucestershire, 2013)

14. Liverpool City Council, Maritime mercantile city for inscription on the World Heritage List (Liverpool University Press, Liverpool, 2005)

15. D. Rodwell, J. of Archit. Conserv. 14(2), 83-106 (2008)

16. UNESCO, Historic Centre of Saint Petersburg and Related Groups of Monuments (World Heritage Centre, Paris, France, 2013)

17. V. Nefedov, Proceed. of the Latvia Univ. of Agricul. Landscape Archit. and Art 3(3), 5-13 (2013)

18. P. Avery, Tourism, culture, and regeneration (CABI Pub., Wallingford, Oxfordshire, 2006)

19. J. Hargan, Brit. Heritage 27(6), 42-49 (2008)

20. B.M. Kirikov, Alexander Dmitriev. Arhitektor pervoj poloviny XX veka (Kolo, Saint Petersburg, 2009)

21. M. Shtiglits, Vest. Grazhd. Inzh. - Bul. of Civ. Engineers 1(30), 52-57 (2012)

22. C. Cecil, St. Petersburg: Heritage at risk. MAPS (The Moscow Architecture Preservation Society Zhivoy Gorod, Moscow, 2012)

23. S. Grishin, A. Pastukh, Vestnik. Zodchij. 21 vek - Bull. Architect. 21st Cent. 2(22), 40-43 (2006) 